\title{
STANDARD WYKONYWANIA ZAWODU FIZJOTERAPEUTY - OCENA PRZYJĘTEGO STANU PRAWNEGO
}

\section{Wprowadzenie}

Z dniem 31 maja 2016 r. weszły w życie przepisy ustawy z dnia 25 września 2015 r. o zawodzie fizjoterapeuty ${ }^{1}$, czego skutkiem było kompleksowe i ustawowe uregulowanie zasad wykonywania zawodu przez fizjoterapeutę. Nastąpiło to dopiero w 2015 r., ale już od lat 80. ubiegłego wieku opracowywano w Polsce wiele projektów, których celem była kompleksowa regulacja powyższej profesji ${ }^{2}$. Projekty nie stały się jednak obowiązującymi przepisami prawa. Należy podkreślić, że do dnia wejścia w życie u.z.f. obowiązywały akty prawne dotyczące wykonywania zawodu fizjoterapeuty, jednak - co istotne - nie określały kompleksowo statusu i wykonywania tego zawodu. „Najdokładniejsze, ale także najbardziej rygorystyczne odniesienia do zawodu fizjoterapeuty zawierały [...] przepisy dotyczące systemu publicznego ubezpieczenia zdrowotnego w Polsce" ${ }^{\prime 3}$. Należy nadmienić, że ustawodawca podejmował również próby uregulowania powyższego zawodu w projekcie ustawy o niektórych

* Dr, Uniwersytet Rzeszowski; e-mail: ajacek@univ.rzeszow.pl, ORCID ID: https:/ / orcid.org/0000-0003-2899-2147.

1 Ustawa z dnia 25 września 2015 r. o zawodzie fizjoterapeuty, tekst jednolity: Dz. U. z 2019 r. poz. 952 (dalej: u.z.f.).

2 Zob. M. Migała, Kalendarium prac nad ustawa o zawodzie fizjoterapeuty, "Rehabilitacja w Praktyce" 2015, nr 6, s. 70 i nast.

3 M. Paszkowska, Ustawowe zasady wykonywania zawodu fizjoterapeuty, „Rehabilitacja w Praktyce" 2015, nr 6, s. 72. 
zawodach medycznych ${ }^{4}$ oraz w projekcie ustawy o niektórych zawodach medycznych i zasadach uzyskiwania tytułu specjalisty mających zastosowanie $w$ ochronie zdrowia ${ }^{5}$, jednak jego działania nie zakończyły się kompleksowym ujęciem zagadnienia. Uchwalenie przepisów ustawy o zawodzie fizjoterapeuty było możliwe dzięki wieloletnim staraniom, czynionym przez Polskie Towarzystwo Fizjoterapii ${ }^{6}$.

Celem niniejszych rozważań jest ocena standardu wykonywania zawodu fizjoterapeuty na podstawie przyjętego stanu prawnego. Zanim jednak w dalszej części artykułu dojdzie do analizy standardu wykonywania powyższej profesji niniejsze rozważania wypada rozpocząć od ustalenia statusu prawnego zawodu fizjoterapeuty.

\section{Status zawodu fizjoterapeuty}

Przed wejściem w życie przepisów u.z.f. w literaturze przedmiotu zgłaszano wątpliwości odnośnie do statusu prawnego zawodu fizjoterapeuty oraz co do zaliczenia zawodu fizjoterapeuty do zawodów medycznych ${ }^{7}$. Wątpliwości te zostały jednak rozwiązane przez ustawodawcę, który w art. 2 u.z.f. jednoznacznie określił, że zawód fizjoterapeuty jest samodzielnym zawodem medycznym.

Wykonywanie zawodu fizjoterapeuty regulują w szczególności przepisy u.z.f. Należy również dodać, że zawód fizjoterapeuty został

4 Zob. projekt ustawy o niektórych zawodach medycznych, Druk sejmowy VI kadencji Nr 846, http:/ / orka.sejm.gov.pl/Druki6ka.nsf/0/CF32998F2C2012BBC1257491004976 68/\$file/846.pdf [dostęp: 11.02.2020 r.].

5 Zob. projekt ustawy o niektórych zawodach medycznych i zasadach uzyskiwania tytułu specjalisty mających zastosowanie w ochronie zdrowia, Druk sejmowy V kadencji Nr 1553, http:/ / orka.sejm.gov.pl/Druki5ka.nsf/0/9D4D5604FCE6B77DC12572AC006202 A6/\$file/1553.pdf [dostęp: 11.02.2020 r.].

6 Zob. K. Wierdak, M. Kiljański, "Dtugi marsz” do ustawy określającej zawód fizjoterapeuty jako samodzielny zawód medyczny, „Fizjoterapia Polska” 2015, nr 4, s. 108-115.

7 Zob. M. Łakomski i in., Prawne podstawy zawodu fizjoterapeuty i potrzeba ustawy o zawodzie, „Praktyczna Fizjoterapia i Rehabilitacja” 2014, nr 54, s. 48 i nast. Odmienne stanowisko mieli A. Jacek i S. Porada, zob. ciż, Aspekty prawne wykonywania zawodu fizjoterapeuty w Polsce, „Przegląd Medyczny Uniwersytetu Rzeszowskiego i Narodowego Instytutu Leków w Warszawie" 2012, z. 1, s. 125. 
sklasyfikowany w kategorii - specjalista ochrony zdrowia (Nr 228) ${ }^{8}$ przy jednoczesnym rozróżnieniu: fizjoterapeutów (Nr 229201) oraz specjalistów fizjoterapii (Nr 229202). W klasyfikacji wyróżniono również techników fizjoterapii (Nr 325401) ujętych w grupie - inny średni personel do spraw zdrowia (Nr 325). W tym miejscu należy również dodać, że fizjoterapeuci, tak samo jak inne zawody medyczne, mają również możliwość uzyskania tytułu specjalisty $\mathrm{w}$ zakresie fizjoterapii.

Analizując status prawny zawodu fizjoterapeuty trzeba również określić, czy powyższy zawód jest zawodem wolnym, regulowanym oraz zawodem zaufania publicznego. W obowiązujących przepisach brak jest legalnych definicji powyższych pojęć, natomiast zostały one sprecyzowane w literaturze.

Odnosząc się do pojęcia wolnego zawodu należy zwrócić uwagę, że ustawodawca stosuje powyższe pojęcie $\mathrm{w}$ różnych aktach prawnych, np. w ustawie z dnia 15 września 2000 r. - Kodeks spółek handlowych ${ }^{9}$ oraz w ustawie z dnia 29 sierpnia 1997 r. - Ordynacja podatkowa ${ }^{10}$. W art. 86 k.s.h. ustawodawca posłużył się pojęciem wolnego zawodu precyzując możliwość tworzenia spółki partnerskiej przez partnerów w celu tworzenia wolnego zawodu. Natomiast art. 88 k.s.h. zawiera katalog zamknięty profesji, które ustawodawca uznał za wolne zawody ${ }^{11}$. Odnosząc się natomiast do pojęcia wolnego zawodu w przepisach ustawy Ordynacja podatkowa podkreślić należy, że ustawodawca w art. 3 pkt 9 uznał wykonywanie wolnych zawodów za rodzaj działalności gospodarczej.

Analizując pojęcie wolnego zawodu powinno się również zwrócić uwagę na kryteria jego wykonywania. W związku z powyższym należy

8 Rozporządzenie Ministra Pracy i Polityki Społecznej z dnia 7 sierpnia 2014 r. w sprawie klasyfikacji zawodów i specjalności na potrzeby rynku pracy oraz zakresu jej stosowania, tekst jednolity: Dz. U z 2018 r. poz. 227.

9 Ustawa z dnia 15 września 2000 r. - Kodeks spółek handlowych, tekst jednolity: Dz. U. z 2019 r. poz. 505 z późn. zm. (dalej: k.s.h.).

10 Ustawa z dnia 29 sierpnia 1997 r. - Ordynacja podatkowa, tekst jednolity: Dz. U. z 2019 r. poz. 900 z późn. zm.

11 Do dnia 31 marca 2019 r. wolnymi zawodami uprawnionymi do utworzenia spółki partnerskiej są: adwokat, aptekarz, architekt, inżynier budownictwa, biegły rewident, broker ubezpieczeniowy, doradca podatkowy, makler papierów wartościowych, doradca inwestycyjny, księgowy, lekarz, lekarz dentysta, lekarz weterynarii, notariusz, pielęgniarka, położna, radca prawny, rzecznik patentowy, rzeczoznawca majątkowy i tłumacz przysięgły. 
odnieść się do wyroku Trybunału Konstytucyjnego (TK) z dnia 19 października 1999 r., w którym wskazał:

w odniesieniu do wolnych zawodów treścią wolności wykonywania zawodu jest stworzenie sytuacji prawnej, w której: po pierwsze, każdy mieć będzie swobodny dostęp do wykonywania zawodu, warunkowany tylko talentami i kwalifikacjami; po drugie, mieć będzie następnie rzeczywistą możliwość wykonywania swojego zawodu oraz - po trzecie, nie będzie przy wykonywaniu zawodu poddany rygorom podporządkowania, które charakteryzują świadczenie prac ${ }^{12}$.

Nawiązując do poglądów doktryny, co do pojęcia wolnego zawodu, należy przywołać stanowisko A. Krasnowolskiego, który ujmuje wolny zawód jako:

pojęcie odnoszące się do zawodu wykonywanego na podstawie odpowiedniego wykształcenia, samodzielnie (co nie oznacza, że koniecznie indywidualnie) i na własną odpowiedzialność w sposób niezależny zawodowo, $\mathrm{w}$ celu oferowania usług intelektualnych lub koncepcyjnych $\mathrm{w}$ interesie klienta lub w interesie publicznym. Ważnymi cechami właściwymi wykonywaniu wolnego zawodu jest misja wykonywania zawodu, przestrzeganie reguł deontologicznych, zapewnienie klientom tajemnicy zawodowej i zaufania oraz ponoszenie szczególnej odpowiedzialności z racji sposobu wykonania zlecenia ${ }^{13}$.

Natomiast J. Jacyszyn precyzuje cechy, które składają się na „wolny zawód" wskazując m.in. na kwalifikowane, szczególne wykształcenie, niezależność zawodową, specyficzną odpowiedzialność cywilną, a także porządkową, czy też korporacyjną, oraz obowiązkową przynależność do samorządu zawodowego ${ }^{14}$. Autor podkreśla również:

wykonywanie wolnych zawodów odbywa się na podstawie regulacji szczegółowych, one bowiem stanowią normatywne instrumentarium wykonywania

12 Wyrok TK z dnia 19 października 1999 r., SK 4/99, OTK ZU 1999, z. 6, poz. 119.

13 A. Krasnowolski, Zawody zaufania publicznego, zawody regulowane oraz wolne zawody. Geneza, funkcjonowanie oraz aktualne problemy, Kancelaria Senatu. Biuro Analiz i Dokumentacji, Opracowania tematyczne OT-625, Warszawa 2013, https:/ /www.senat.gov.pl/gfx/ senat/pl/senatopracowania/56/plik/ot-625_.pdf [dostęp: 3.02.2019 r.].

14 Zob. J. Jacyszyn, Wolność gospodarcza a wolny zawód, „Przegląd Prawa i Administracji” 2015, t. 103, s. 238. 
wolnego zawodu, wskazując przy tym formy organizacyjnoprawne, za pomocą których wolne zawody świadczą swoje usługi ${ }^{15}$.

Analizując przepisy u.z.f. należy jednoznacznie stwierdzić, że ustawodawca w art. 4 ust. 4 powyższej ustawy wskazał na wymóg posiadania wysokich kwalifikacji zawodowych do wykonywania zawodu fizjoterapeuty zaliczając do nich nie tylko wiedzę poświadczoną dyplomem ukończenia wyższych studiów na kierunku fizjoterapia, ale również staż pracy, który ma być wyznacznikiem nabytych umiejętności. Obowiązek posiadania odpowiednich kwalifikacji został również podkreślony przez ustawodawcę $\mathrm{w}$ art. 13 ust. 3 pkt 1 u.z.f. poprzez sprecyzowanie, że np. fizjoterapeuci, którzy rozpoczną studia po dniu 1 października 2017 r., będą musieli ukończyć jednolite pięcioletnie studia wyższe, odbyć sześciomiesięczną praktykę zawodową i zdać Państwowy Egzamin Fizjoterapeutyczny. W przypadku niezależności zawodowej, jako kolejnej cechy wolnego zawodu, należy wskazać, że w art. 2 u.z.f. ustawodawca sprecyzował samodzielność zawodu fizjoterapeuty. W tym miejscu należy przywołać pogląd P. Kłuska, który słusznie wskazuje, że: „w przypadku «samodzielności» należy natomiast pamiętać, że jedynie fizjoterapeuta, który uzyskał tytuł zawodowy w określony sposób, a w niektórych przypadkach odbył także dodatkową praktykę, może samodzielnie wykonywać swój zawód"16. Przepisy u.z.f. określają również obowiązkową przynależność fizjoterapeutów do samorządu zawodowego oraz odpowiedzialność zawodową za naruszenie zasad etyki zawodowej lub przepisów dotyczących wykonywania zawodu. Powyższe ustalenia pozwalają więc jednoznacznie stwierdzić, że zawód fizjoterapeuty należy zaliczyć do wolnych zawodów. Należy jednak podkreślić, że, pomimo zaliczenia powyższej profesji do wolnych zawodów, przepisy u.z.f., które weszły w życie z dniem 31 maja 2016 r., nie umożliwiały fizjoterapeutom wykonywania zawodu $\mathrm{w}$ ramach praktyki zawodowej. Ustawodawca podjął zatem prace legislacyjne nad projektem ustawy o zmianie ustawy o działalności leczniczej oraz niektórych ustaw ${ }^{17}$, której celem było umożliwienie przedstawicielom tej profesji wykonywania

15 J. Jacyszyn, Przedsiębiorca a wolny zawód, „Rejent” 2003, nr 10, s. 73.

16 P. Kłusek, Fizjoterapeuta jako wolny zawód i zawód zaufania publicznego, „Rozprawy Naukowe Akademii Wychowania Fizycznego we Wrocławiu" 2016, t. 53, s. 47.

17 Projekt ustawy o zmianie ustawy o działalności leczniczej oraz niektórych ustaw, Druk sejmowy VIII kadencji Nr 2903, http:/ / orka.sejm.gov.pl/Druki8ka.nsf/0/FB793A4 A5AE5FCF8C12583280031AFD8/\%24File/2903.pdf [dostęp: 11.02.2020 r.]. 
zawodu w ramach praktyki zawodowej. Rezultatem prac ustawodawcy jest przyjęcie $\mathrm{w}$ ustawie $\mathrm{z}$ dnia 9 listopada 2018 r. o zmianie ustawy o działalności leczniczej i niektórych ustaw ${ }^{18}$ zmian dotyczących wykonywania zawodu przez fizjoterapeutę. Należy przyjąć z aprobatą zmiany, które weszły w życie z dniem 1 kwietnia 2019 r. z uwagi na to, że ustawodawca zaliczył zawód fizjoterapeuty do wolnych zawodów, jak też uregulował możliwość wykonywania zawodu przez fizjoterapeutę w ramach praktyki zawodowej.

Kontynuując dalsze rozważania co do ustalenia, czy zawód fizjoterapeuty jest zawodem regulowanym oraz zawodem zaufania publicznego należy przywołać art. 3 ust. 1 lit. a Dyrektywy 2005/36/WE Parlamentu Europejskiego oraz Rady z dnia 7 września 2005 r. w sprawie uznawania kwalifikacji zawodowych ${ }^{19}$. Powyższy przepis definiuje pojęcie zawodu regulowanego precyzując, że:

jest to działalność zawodowa lub zespół działalności zawodowych, których podjęcie, wykonywanie, lub jeden ze sposobów wykonywania wymaga, bezpośrednio bądź pośrednio, na mocy przepisów ustawowych, wykonawczych lub administracyjnych, posiadania specjalnych kwalifikacji zawodowych; w szczególności używanie tytułu zawodowego zastrzeżonego na mocy przepisów ustawowych, wykonawczych i administracyjnych dla osób posiadających odpowiednie kwalifikacje zawodowe stanowi sposób wykonywania działalności zawodowej $[\ldots]^{20}$.

W odniesieniu do powyższej definicji należy wskazać, że przesłankami zaklasyfikowania danego zawodu do zawodu regulowanego jest spełnienie wymagań ściśle określonych $\mathrm{w}$ przepisach prawa poprzez posiadanie

18 Ustawa z dnia 9 listopada 2018 r. o zmianie ustawy o działalności leczniczej i niektórych ustaw, Dz. U. z 2018 r. poz. 2219.

19 Dyrektywa 2005/36/WE Parlamentu Europejskiego oraz Rady z dnia 7 września 2005 r. w sprawie uznawania kwalifikacji zawodowych, Dz. Urz. UE L 255 z 30.09.2005, s. $22-142$.

20 Zbliżoną definicję zawodu regulowanego określa art. 5 pkt 4 ustawy z dnia 22 grudnia 2015 r. o zasadach uznawania kwalifikacji nabytych w państwach członkowskich Unii Europejskiej (tekst jednolity: Dz. U. z 2020 r. poz. 220) precyzując, że jest to: „zespół czynności zawodowych, których wykonywanie jest uzależnione od posiadania określonych w przepisach regulacyjnych formalnych kwalifikacji niezbędnych do wykonywania tych czynności zawodowych oraz, o ile jest to wymagane, od spełnienia innych warunków określonych w tych przepisach". 
specjalnych kwalifikacji zawodowych oraz używanie tytułu zawodowego. Natomiast nawiązując do poglądów polskiej doktryny na temat definicji zawodu regulowanego należy ponownie przedstawić stanowisko A. Krasnowolskiego, który ujmuje zawód regulowany jako:

zawód, którego wykonywanie wymaga posiadania określonych kwalifikacji i dozwolone jest dopiero po uzyskaniu zezwolenia, które można zdobyć tylko po spełnieniu wymogów określonych przepisami prawnymi danego państwa (np. zdanie egzaminu, ukończenie wymaganej praktyki zawodowej, uzyskanie wpisu na listę, ukończenie właściwego kształcenia czy szkolenia ${ }^{21}$.

W związku z powyższym należy odwołać się do przepisów u.z.f., w których ustawodawca sprecyzował kryteria, których spełnienie warunkuje wykonywanie zawodu fizjoterapeuty m.in. odbycie sześciomiesięcznej praktyki zawodowej czy też złożenie Państwowego Egzaminu Fizjoterapeutycznego. Powyższa analiza prowadzi zatem do zaliczenia zawodu fizjoterapeuty do zawodów regulowanych.

Powracając do dalszych rozważań dotyczących ustalenia, czy zawód fizjoterapeuty jest zawodem zaufania publicznego należy wskazać, że art. 17 ust. 1 Konstytucji Rzeczypospolitej Polskiej zawiera pojęcie „zawodu zaufania publicznego" w kontekście możliwości tworzenia w drodze ustawy samorządów zawodowych reprezentujących osoby wykonujące zawody zaufania publicznego i sprawujących pieczę nad należytym wykonywaniem tych zawodów w granicach interesu publicznego i dla jego ochrony. Powyższy przepis nie określa jednak przesłanek, na podstawie których należy kwalifikować poszczególne zawody do zawodów zaufania publicznego. W literaturze przedmiotu za takie kryteria przyjmuje się regulowany charakter; osobisty sposób świadczenia usług; kwalifikowane wykształcenie; aksjologię wykonywania zawodu; strukturę wykonywania wolnego zawodu; niezależność zawodową; etos zawodowy; stan i sposób zorganizowania; wynagrodzenie; tajemnicę zawodową; szczególną odpowiedzialność oraz samorządność korporacyjną ${ }^{22}$. Należy także dodać, że w doktrynie wśród cech zawodu zaufania publicznego zauważa się również, że wykonuje się go nie dla zysku, ale w celu zaspokojenia interesu

21 A. Krasnowolski, Zawody zaufania publicznego...

${ }^{22}$ Zob. J. Jacyszyn, Wykonywanie wolnych zawodów w Polsce, Warszawa 2004, s. 42-43. 
publicznego ${ }^{23}$. Wyróżnikiem zawodów zaufania publicznego jest m.in. ich quasi misyjność, czyli wykonywanie ich w celu zaspokojenia interesu publicznego ${ }^{24}$.

Jak zostało wcześniej wspomniane, w obowiązujących aktach prawnych brak jest legalnej definicji zawodu zaufania publicznego. Próby wyjaśnienia tego pojęcia podjęto natomiast w literaturze i orzecznictwie. Paweł Sarnecki wskazuje, że:

zawód zaufania publicznego to zawód polegający na obsłudze osobistych potrzeb ludzkich, wiążący się z przyjmowaniem informacji dotyczących życia osobistego i zorganizowany $\mathrm{w}$ sposób uzasadniający przekonanie społeczne o właściwym dla interesów jednostki wykorzystywaniu tych informacji przez świadczących usługi. Wykonywanie zawodu zaufania publicznego określane jest dodatkowo normami etyki zawodowej, szczególną treścią ślubowania, tradycją korporacji zawodowej, czy szczególnym charakterem wykształcenia wyższego i uzyskanej specjalizacji. Dopuszczenie przez konkretną osobę osoby świadczącej ten zawód do sfery jej prywatności musi bowiem mieć jako swój korelat zaufanie, że dopuszczenie to nie zostanie nadużyte ${ }^{25}$.

Anna Młynarska-Sobaczewska zwraca zaś uwagę, że zawody zaufania publicznego: „to zawody, których wykonywanie wiąże się ze świadczeniem określonych usług istotnych z punktu widzenia podstawowych dóbr jednostki - takich jak zdrowie, ochrona interesów majątkowych, dóbr osobistych i innych"26. Należy podkreślić, że w orzecznictwie TK nie zdefiniowano pojęcia zawodu zaufania publicznego. Trybunał wskazał

23 Zob. B. Banaszak, Konstytucja Rzeczypospolitej Polskiej. Komentarz, Warszawa 2009, s. 117.

${ }^{24}$ Zob. W.J. Wołpiuk, Zawód zaufania publicznego z perspektywy prawa konstytucyjnego, [w:] Senat Rzeczypospolitej Polskiej, Zawody zaufania publicznego a interes publiczny - korporacyjna reglamentacja versus wolność wykonywania zawodu. Materiaty z konferencji zorganizowanej przez Komisje Polityki Społecznej i Zdrowia Senatu RP przy wspótudziale Ministerstwa Pracy i Polityki Społecznej pod patronatem Marszatka Senatu RP Longina Pastusiaka 8 kwietnia 2002 r., Warszawa 2002, s. 21, http://ww2.senat.pl/k5/agenda/seminar/a/020408.pdf [dostęp: 5.02.2019 r.].

25 P. Sarnecki, Komentarz do art. 17, [w:] L. Garlicki (red.), Konstytucja Rzeczypospolitej Polskiej. Komentarz, t. 4, Warszawa 2005, s. 2.

26 A. Młynarska-Sobaczewska, Zawody zaufania publicznego, [w:] W. Skrzydło, S. Grabowska, R. Grabowski (red.), Konstytucja Rzeczypospolitej Polskiej. Komentarz Encyklopedyczny, Warszawa 2009, s. 740. 
jedynie na cechy zawodu zaufania publicznego zaliczając do nich: „normy etyki zawodowej, szczególną treść ślubowania, tradycję korporacji zawodowej czy szczególny charakter wykształcenia wyższego i uzyskanej specjalizacji" 27 .

Zcałą pewnością zawód fizjoterapeuty należy zaliczyć do zawodów zaufania publicznego. W powyższym kontekście należy wskazać, że świadczenia zdrowotne realizowane przez fizjoterapeutów mają na celu ochronę dóbr o konstytucyjnym charakterze jakim jest życie i zdrowie pacjentów. Jak słusznie wskazuje D. Karkowska: „podejmowanie działań medycznych [przez fizjoterapeutów - A.J.] na rzecz ochrony zdrowia i życia pacjenta wymaga osobistego charakteru świadczonych usług" 28 . Trzeba także dodać, że korzystającymi ze świadczeń, które wykonują fizjoterapeuci są wyłącznie pacjenci, co oznacza wchodzenie przez fizjoterapeutów w relacje $\mathrm{z}$ osobami fizycznymi w razie wystąpienia potencjalnego lub realnego zagrożenia życia lub zdrowia. Należy także zaznaczyć, że art. 4 ust. 1 u.z.f. precyzuje również obowiązek wykonywania zawodu przez fizjoterapeutę zgodnie z zasadami należytej staranności, poszanowania praw pacjenta, a także dbałości o jego bezpieczeństwo. Podobną normę zawiera art. 3 Zasad etyki zawodowej fizjoterapeuty precyzując: „W pracy zawodowej,

27 Wyrok TK z dnia 2 lipca 2007 r., K 41/05, OTK ZU 2007, z. 7A, poz. 72. Natomiast w wyroku z dnia 24 marca 2015 r. TK sprecyzował również cechy zawodu zaufania publicznego wskazując na: „konieczność zapewnienia prawidłowego i zgodnego z interesem publicznym wykonywania zawodu, ze względu na znaczenie, jakie dana dziedzina aktywności zawodowej ma w społeczeństwie, udzielanie świadczeń i wchodzenie przez przedstawicieli omawianych zawodów w kontakty z osobami fizycznymi w razie wystąpienia potencjalnego lub realnego zagrożenia dóbr o szczególnym charakterze (np. życia, zdrowia, wolności, godności, dobrego imienia), staranność i dbałość przedstawicieli omawianych zawodów o interesy osób korzystających z ich usług, troska o ich osobiste potrzeby, a także zapewnienie ochrony gwarantowanych przez Konstytucję praw podmiotowych jednostek, wymaganie szczególnych kwalifikacji do wykonywania omawianych zawodów, obejmujących nie tylko odpowiednie, formalne wykształcenie, ale także nabyte doświadczenie oraz dawanie rękojmi należytego i zgodnego z interesem publicznym wykonywania zawodu, z uwzględnieniem szczególnych norm deontologii zawodowej, pozyskiwanie informacji osobistych i dotyczących życia prywatnego osób korzystających z usług przedstawicieli zawodu zaufania publicznego stanowiących tajemnicę zawodową oraz względną samodzielność wykonywania zawodu", wyrok TK z dnia 24 marca 2015 r., K 19/14, OTK ZU 2015, z. 3A, poz. 32.

28 D. Karkowska, Zawody medyczne, Warszawa 2012, s. 244. 
fizjoterapeuta, stawia dobro człowieka ponad wszystkie dobra" ${ }^{29}$. Przepisy u.z.f. precyzują też kryteria, których spełnienie warunkuje wykonywanie zawodu fizjoterapeuty. Na zaliczenie zawodu fizjoterapeuty do zawodów zaufania publicznego wskazuje również wynikający z art. 4 ust. 1 u.z.f. obowiązek wykonywania zawodu zgodnie z zasadami etyki zawodowej. Zaznaczyć także należy, że fizjoterapeuta na podstawie art. 7 u.z.f. jest uprawniony do wglądu do dokumentacji medycznej pacjenta oraz do uzyskania od podmiotu udzielającego świadczeń zdrowotnych pełnej informacji [...] o stanie zdrowia pacjenta, rozpoznaniu, proponowanych metodach diagnostycznych, leczniczych, rehabilitacyjnych, zapobiegawczych i dających się przewidzieć następstwach podejmowanych działań, $\mathrm{w}$ zakresie niezbędnym do udzielanych przez siebie świadczeń zdrowotnych. Ponad to $w$ art. 9 u.z.f. ustawodawca określił obowiązek zachowania przez fizjoterapeutę uzyskanych informacji w tajemnicy. Nawiązując do samodzielności zawodowej fizjoterapeuty należy przypomnieć, że w zależności od posiadanego wykształcenia fizjoterapeuta może wykonywać zawód samodzielnie lub też dodatkowo powinien posiadać odpowiedni okres doświadczenia zawodowego. Biorąc pod uwage powyższe należy jednoznacznie stwierdzić, że zawód fizjoterapeuty jest zawodem zaufania publicznego.

\section{Zakres kompetencji fizjoterapeuty}

Wykonywanie zawodu fizjoterapeuty polega na udzielaniu świadczeń zdrowotnych przez osobę posiadającą odpowiednie kwalifikacje oraz prawo wykonywania zawodu fizjoterapeuty. Ustawodawca w art. 4 ust. 2 u.z.f. określił katalog świadczeń zdrowotnych, do których wykonania uprawniony jest fizjoterapeuta wskazując na możliwość wykonania diagnostyki funkcjonalnej pacjenta, kwalifikowanie, planowanie i prowadzenie fizykoterapii, kinezyterapii oraz masażu, zlecanie i dobieranie do potrzeb pacjenta wyrobów medycznych oraz nauczanie pacjentów posługiwania się wyrobami medycznymi. Udzielanie świadczeń

29 Zasady etyki zawodowej fizjoterapeuty przyjęte uchwałą nr 20/I KZF/2016 z dnia 29 grudnia 2016 r. Krajowego Zjazdu Fizjoterapeutów, https:/ /kif.info.pl/file/2017/01/ 20-I-KZF-2016-zal.pdf [dostęp: 11.02.2020 r.]. 
zdrowotnych przez fizjoterapeutę obejmuje również prowadzenie działalności fizjoprofilaktycznej, wydawanie opinii i orzeczeń odnośnie stanu funkcjonalnego osób poddawanych fizjoterapii oraz przebiegu procesu fizjoterapii oraz nauczanie pacjentów mechanizmów kompensacyjnych i adaptacji do zmienionego potencjału funkcji ciała i aktywności. Należy zauważyć, że powyższy katalog jest otwarty oraz ma charakter wyliczenia przykładowego świadczeń zdrowotnych, które należą do kompetencji fizjoterapeuty. Nie powinien on jednak wykraczać poza zakres zadań zawodowych określonych $\mathrm{w}$ art. 4 ust. 2 u.z.f., np. poprzez układanie diety dostosowanej do indywidualnych potrzeb pacjenta czy też suplementowanie pacjenta $\mathrm{w}$ oparciu o naturalne preparaty. $\mathrm{W}$ powyższym kontekście należy także podkreślić, że rozporządzenie Ministra Zdrowia z dnia 27 czerwca 2018 r. w sprawie szczegółowego wykazu czynności zawodowych fizjoterapeuty ${ }^{30}$ nie określa kompetencji fizjoterapeuty do wykonywania wskazanych powyżej czynności.

Analogicznie jak w przypadku innych zawodów medycznych ustawodawca wskazał, że wykonywaniem zawodu fizjoterapeuty jest również nauczanie zawodu fizjoterapeuty, wykonywanie pracy na rzecz doskonalenia zawodowego fizjoterapeutów, prowadzenie prac naukowo-badawczych $\mathrm{w}$ zakresie fizjoterapii, kierowanie pracą zawodową osób wykonujących zawód fizjoterapeuty oraz zatrudnienie na stanowiskach administracyjnych, na których wykonuje się czynności związane z przygotowaniem, organizowaniem lub nadzorem nad udzielaniem świadczeń opieki zdrowotnej. Należy zauważyć, że ustawodawca z dniem 1 kwietnia 2019 r. rozszerzył katalog czynności, których wykonywanie uznaje się również za wykonywanie zawodu fizjoterapeuty precyzując, że jest to również wykonywanie czynności zawodowych w podmiocie, który nie jest podmiotem wykonującym działalność leczniczą, np. w domach opieki społecznej czy też klubach sportowych. Powyższą zmianę przepisów należy ocenić pozytywnie z uwagi na to, że fizjoterapeuci wykonujący te same czynności zawodowe poza podmiotami wykonującymi działalność leczniczą nie będą tracili prawa do udzielania świadczeń zdrowotnych po okresie pięciu lat zatrudnienia w powyższych podmiotach.

30 Rozporządzenie Ministra Zdrowia z dnia 27 czerwca 2018 r. w sprawie szczegółowego wykazu czynności zawodowych fizjoterapeuty, Dz. U. z 2018 r. poz. 1319. 


\section{Wymagania kwalifikacyjne stawiane fizjoterapeutom}

Ustawodawca $\mathrm{w}$ przepisach u.z.f. uzależnił samodzielne udzielanie świadczeń zdrowotnych przez fizjoterapeutę od wykształcenia oraz posiadania odpowiedniego doświadczenia zawodowego ${ }^{31}$. Przede wszystkim należy zaznaczyć, że przepisy u.z.f. jednoznacznie wskazują, że uprawnienie do samodzielnego udzielania świadczeń zdrowotnych posiadają fizjoterapeuci, którzy posiadają tytuł magistra fizjoterapii uzyskany po dniu 1 października 2017 r. lub magistra fizjoterapii i co najmniej trzyletnie doświadczenie $\mathrm{w}$ zawodzie fizjoterapeuty, jak również tytuł licencjata lub zawodowy - technika fizjoterapii i co najmniej sześcioletnie doświadczenie w zawodzie fizjoterapeuty. Przepisy u.z.f. ograniczają jednak samodzielność zawodową dla fizjoterapeutów posiadających tytuł licencjata lub technika fizjoterapii precyzując, że osoby z powyższym wykształceniem nie mogą kwalifikować pacjenta do fizykoterapii i kinezyterapii, a także zlecać wykonania wyrobów medycznych oraz wydawać opinii oraz orzeczeń co do stanu funkcjonalnego osób poddawanych fizjoterapii oraz przebiegu procesu fizjoterapii. Należy także zauważyć, że przepisy u.z.f., które weszły w życie z dniem 1 kwietnia 2019 r. ograniczają samodzielne udzielenie świadczeń zdrowotnych przez fizjoterapeutę nieposiadającego doświadczenia $\mathrm{w}$ zawodzie fizjoterapeuty precyzując, że podstawą udzielania przez niego świadczeń zdrowotnych jest skierowanie lekarza albo innego fizjoterapeuty posiadającego prawo samodzielnego udzielania świadczeń zdrowotnych z zakresu fizjoterapii. Powyższą zmianę należy ocenić pozytywnie z uwagi na to, że przepisy ustawy o zawodzie fizjoterapeuty do dnia 31 marca 2019 r. nie precyzowały zasad udzielania świadczeń zdrowotnych przez fizjoterapeutów nieposiadających wymaganego stażu pracy. Analiza i ocena kompetencji zawodowych fizjoterapeutów wymaga również odwołania się do przywołanych powyżej przepisów rozporządzenia Ministra Zdrowia z dnia 27 czerwca 2018 r. w sprawie szczegółowego wykazu czynności zawodowych fizjoterapeuty. Trzeba wskazać, że ta regulacja precyzuje możliwość wykonywania zadań zawodowych przez fizjoterapeutę od odpowiadającego mu poziomu wykształcenia określając trzy poziomy wykształcenia:

31 Takie stanowisko zajmuje J. Hanc, zob. tenże, Fizjoterapeuta, [w:] R. Kubiak, L. Kubicki (red.), System Prawa Medycznego, t. 1. Pojęcie, źródta i zakres prawa medycznego, Warszawa 2018, s. 368-369. 
poziom podstawowy uzyskany przez osobę, która ukończyła publiczną szkołę policealną lub niepubliczną szkołę policealną o uprawnieniach szkoły publicznej i uzyskała tytuł zawodowy "technik fizjoterapii” oraz osoba, która uzyskała dyplom potwierdzający uzyskanie tytułu licencjata na kierunku fizjoterapia; poziom rozszerzony posiadany przez osobę, która ma dyplom potwierdzający uzyskanie tytułu magistra fizjoterapii; poziom specjalistyczny, który posiada fizjoterapeuta z tytułem specjalisty $w$ dziedzinie fizjoterapii lub tytułem specjalisty rehabilitacji ruchowej II stopnia. Należy zauważyć, że w przypadku poziomu podstawowego wymaganego do wykonywania zadań zawodowych przez fizjoterapeutę zrównano uprawnienia fizjoterapeutów, którzy ukończyli studia I stopnia oraz osób, które ukończyły szkołę policealną ${ }^{32}$. W tym miejscu trzeba zwrócić uwagę na różnice dotyczące efektów kształcenia dla absolwentów szkół policealnych oraz studiów I stopnia na kierunku fizjoterapia, jak też na okres uzyskania uprawnień w celu wykonywania zadań zawodowych przez fizjoterapeutę. Należy również zauważyć, że w powyższej regulacji nie sprecyzowano kompetencji zawodowych fizjoterapeuty dotyczących nauczania, prowadzenia prac naukowo-badawczych, kierowania pracą zawodową osób wykonujących zawód fizjoterapeuty oraz zatrudnienia na stanowiskach administracyjnych ${ }^{33}$. Trzeba $\mathrm{w}$ tym miejscu przypomnieć, że przepisy u.z.f. precyzują, iż powyższe zadania są również wykonywaniem zawodu przez fizjoterapeutę. Wydaje się więc zasadnym doprecyzowanie wskazanej materii $\mathrm{w}$ przepisach rozporządzenia Ministra Zdrowia z dnia 27 czerwca 2018 r. w sprawie szczegółowego wykazu czynności zawodowych fizjoterapeuty.

${ }^{32} \mathrm{~W}$ powyższym kontekście projekt został negatywnie oceniony przez Rektora Wyższej Szkoły Fizjoterapii z siedzibą we Wrocławiu, dr. hab. A. Czamarę, prof. WSF, w piśmie z dnia 16 czerwca 2017 r., zob. https:/ / legislacja.rcl.gov.pl/docs/ /516/12298506/124 33907/12433910/dokument302400.pdf [dostęp: 17.03.2019 r.].

33 Dodać należy, że również przepisy rozporządzenia Ministra Zdrowia nie precyzują kwalifikacji wymaganych do kierowania pracą zawodową osób wykonujących zawód fizjoterapeuty, zob. rozporządzenie Ministra Zdrowia z dnia 20 lipca 2011 r. w sprawie kwalifikacji wymaganych od pracowników na poszczególnych rodzajach stanowisk pracy w podmiotach leczniczych niebędących przedsiębiorcami, Dz. U. z 2011 r. Nr 151, poz. 896. 


\section{Wykonywanie zawodu fizjoterapeuty a prawa pacjenta}

Standard wykonywania zawodu fizjoterapeuty precyzuje art. 4 ust. 1 u.z.f. określając, że fizjoterapeuta zobowiązany jest do wykonywania zawodu z należytą starannością, zgodnie z zasadami etyki zawodowej, poszanowaniem praw pacjenta, dbałością o jego bezpieczeństwo i wykorzystując wskazania aktualnej wiedzy medycznej. Należy podkreślić, że powyższe kryteria dla wykonywania zawodu przez fizjoterapeutę są zbliżone do innych zawodów medycznych, np. lekarzy, diagnostów laboratoryjnych oraz pielęgniarek i położnych.

Odnosząc się do pierwszego pojęcia należytej staranności w kontekście standardu wykonywania zawodu przez fizjoterapeutę zauważyć należy, że powyższe pojęcie zostało wskazane w art. 355 Kodeksu cywilnego $^{34} \mathrm{w}$ celu określenia obowiązków dłużnika wobec wierzyciela. Autorzy Z. Banaszczyk i P. Granecki ujmują należytą staranność jako:

obiektywnie istniejący wzorzec postępowania, stworzony w celu jak najlepszego, poprawnego wykonania zobowiązań, a jednocześnie zabezpieczający interesy zobowiązanych przez odniesienie treści staranności do danego rodzaju stosunków. Niezadowalające w porównaniu z wzorcowym zachowaniem się dłużnika sprowadza na owego niestarannego dłużnika odpowiedzialność odszkodowawcząa

Podobnie ujmuje należytą staranność W. Borysiak precyzując, że jest to: „sposób postępowania dłużnika odpowiadający wymaganiom zawartym w obiektywnym wzorcu postępowania, który jest tworzony na tle danego stosunku zobowiązaniowego"36. Pojęcie należytej staranności było również wielokrotnie przedmiotem oceny orzecznictwa w odniesieniu do zachowania należytej staranności przez lekarza. Orzecznictwo dotyczące należytej staranności lekarza można zastosować w celu określenia należytej staranności przez fizjoterapeutę. W powyższym kontekście należy wskazać, że określenia wzorca należytej staranności dokonał Sąd Apelacyjny w Łodzi w wyroku z dnia 16 stycznia 2014 r. precyzując, że:

34 Ustawa z dnia 23 kwietnia 1964 r. - Kodeks cywilny, tekst jednolity: Dz. U. z 2019 r. poz. 1145 z późn. zm.

35 Z. Banaszczyk, P. Granecki, O istocie należytej staranności, „Palestra” 2002, nr 7/ 8, s. 19.

36 W. Borysiak, [w:] K. Osajda (red.), Kodeks cywilny. Komentarz, t. 3a. Zobowiązania. Część ogólna, Warszawa 2017, teza 3, Legalis. 
„ten wzorzec kreowany jest na podstawie reguł współżycia społecznego, przepisów prawnych, zwyczajów, swoistych «kodeksów zawodowych», pragmatyk zawodowych itp." ${ }^{37}$ Natomiast w wyroku z dnia 12 kwietnia 2017 r. tenże sąd wskazał, że: „Brak [...] przedstawienia dokumentacji medycznej leczenia [...] należy utożsamiać z naruszeniem tejże [należytej - A.J.] staranności, co więcej, może oznaczać, że taka dokumentacja w ogóle nie była prowadzona"38. Z przywołanych wyżej orzeczeń wynika, że należytą staranność fizjoterapeuty precyzują w szczególności przepisy u.z.f. oraz pozostałe akty prawne dotyczące wykonywania zawodu, normy etyki zawodowej fizjoterapeutów oraz wytyczne Krajowej Rady Fizjoterapeutów. Należy także zaznaczyć, że należyta staranność fizjoterapeuty obejmuje również obowiązek prowadzenia przez fizjoterapeutę dokumentacji medycznej.

W celu określenia należytej staranności przez fizjoterapeutę należy również przywołać wyrok Sądu Apelacyjnego w Warszawie z dnia 4 marca 2015 r., w którym ujęto, że:

należyte wykonywanie zawodu lekarza obejmuje zapoznanie się z właściwościami stosowanych środków, zarówno leków, jak i wyrobów medycznych, przeciwwskazaniami i ostrzeżeniami producentów. Brak takiej wiedzy uniemożliwia podjęcie rzetelnej decyzji o zastosowanym leczeniu i jego przeprowadzenie. Co więcej, im większe zagrożenie może stwarzać dana procedura, tym większa powinna być staranność lekarza ${ }^{39}$.

Trzeba podkreślić, że powyższy wyrok należy również zastosować do udzielania świadczeń zdrowotnych przez fizjoterapeutów z uwagi na to, że w art. 4 ust. 2 pkt 5-7 u.z.f. określono uprawnienia fizjoterapeuty do zlecania wyrobów medycznych, dobierania do potrzeb pacjenta oraz nauczania pacjentów posługiwania się wyrobami medycznymi. Zatem w powyższym przypadku udzielanie świadczeń zdrowotnych przez fizjoterapeutów z zachowaniem należytej staranności powinno

37 Wyrok Sądu Apelacyjnego w Łodzi z dnia 16 stycznia 2014 r., I ACa1148/12, Legalis.

38 Wyrok Sądu Apelacyjnego w Łodzi z dnia 12 kwietnia 2017 r., I ACa 1327/16, http:/ / orzeczenia.lodz.sa.gov.pl/content/\$N/152500000000503_I_ACa_001327_2016_ Uz_2017-04-12_001 [dostęp: 16.02.2019 r.].

39 Wyrok Sądu Apelacyjnego w Warszawie z dnia 4 marca 2015 r., I ACa 515/14, Legalis. 
obejmować również wiedzę fizjoterapeutów co do stosowania wyrobów medycznych ${ }^{40}$.

Konstatując, analiza zarówno literatury przedmiotu oraz przywołanego orzecznictwa prowadzi do wniosku, że wzorzec należytej staranności w przypadku wykonywania zawodu przez fizjoterapeutę będą precyzować w szczególności przepisy u.z.f., pozostałe akty prawne dotyczące wykonywania powyższej profesji, jak również wytyczne Krajowej Rady Fizjoterapeutów.

Przechodząc do analizy udzielania świadczeń zdrowotnych przez fizjoterapeutów zgodnie z zasadami etyki zawodowej - jako kolejnego kryterium dotyczącego standardu wykonywania zawodu przez fizjoterapeutę - należy jednoznacznie wskazać, że zasady etyki zawodowej fizjoterapeuty zostały określone w uchwale Krajowej Rady Fizjoterapeutów nr 20/I KZF/2016 z dnia 29 grudnia 2016 r. w sprawie Zasad etyki zawodowej fizjoterapeuty ${ }^{41}$. Jak słusznie wskazuje E. Sarnacka dokument nie został nazwany kodeksem, lecz jedynie zbiorem zasad. Co więcej - brak w nim wyodrębnionych rozdziałów i jest zdecydowanie najkrótszy z kodeksów etycznych zawodów medycznych - składa się tylko z 10 artykułów ${ }^{42}$. Powyższy dokument zawiera jednak normy deontologiczne określające wykonywanie zawodu fizjoterapeuty obligując przedstawicieli powyższej profesji m.in. do wykonywania zawodu w zakresie posiadanej wiedzy, umiejętności i kompetencji społecznych (art. 2), określając obowiązki fizjoterapeuty dotyczące wykonywania zawodu w warunkach zapewniających bezpieczeństwo i prawidłowe udzielanie świadczeń (art. 6) oraz dochowania tajemnicy zawodowej (art. 10).

Odnośnie do kolejnego kryterium określającego standard wykonywania zawodu fizjoterapeuty $\mathrm{z}$ uwzględnieniem poszanowania praw pacjenta należy podkreślić, że przepisy u.z.f. precyzują obowiązek przestrzegania przez fizjoterapeutę praw pacjenta na kilku płaszczyznach. W związku z powyższym należy podkreślić obowiązek informacyjny fizjoterapeuty dotyczący poinformowania pacjenta o jego prawach

40 Zob. E. Sarnacka, Standard wykonywania zawodu fizjoterapeuty na tle standardów wybranych zawodów medycznych, [w:] A. Górski, E. Sarnacka, M. Grassmann (red.), Standard wykonywania zawodów medycznych, Warszawa 2019, s. 182.

41 Uchwała Krajowej Rady Fizjoterapeutów nr 20/I KZF/2016 z dnia 29 grudnia 2016 r. w sprawie Zasad etyki zawodowej fizjoterapeuty, https://kif.info.pl/file/2017/01/20-IKZF-2016-zal.pdf [dostęp: 11.02.2020 r.].

42 E. Sarnacka, Standard wykonywania zawodu..., s. 187. 
określonych w przepisach ustawy z dnia 6 listopada 2008 r. o prawach pacjenta i Rzeczniku Praw Pacjenta ${ }^{43}$ oraz udzielenia informacji pacjentowi lub jego przedstawicielowi ustawowemu albo osobie bliskiej lub opiekunowi faktycznemu w zakresie niezbędnym do udzielanych przez siebie świadczeń zdrowotnych. Należy również zauważyć, że przepisy u.z.f. obligują również fizjoterapeutę do zachowania tajemnicy związanej z pacjentem, uzyskanych w związku z wykonywaniem zawodu. Fizjoterapeuta zobowiązany jest również do prowadzenia i udostępniania dokumentacji medycznej na zasadach określonych w przepisach u.p.p. Trzeba także zaznaczyć, że przed udzieleniem świadczenia zdrowotnego przez fizjoterapeutę pacjent powinien wyrazić świadomą zgodę na świadczenie zdrowotne. Wyrażenie zgody przez pacjenta powinno zostać poprzedzone udzieleniem informacji pacjentowi przez fizjoterapeutę na temat m.in. stanu zdrowia, proponowanych oraz możliwych metodach diagnostycznych i terapeutycznych, a także dających się przewidzieć następstwach medycznych rekomendowanych działań ${ }^{44}$.

Kontynuując dalszą analizę dotyczącą oceny standardu wykonywania zawodu przez fizjoterapeutę należy zwrócić uwagę na dbałość o bezpieczeństwo pacjenta - jako kolejne kryterium dotyczące wykonywania powyższej profesji. W literaturze przedmiotu słusznie wskazuje się, że dbałość o bezpieczeństwo pacjenta przez fizjoterapeutę oznacza, że: „fizjoterapeuta w świetle prawa stał się bowiem formalnym gwarantem bezpieczeństwa pacjenta, wobec którego podejmuje świadczenia zdrowotne i który ponosi odpowiedzialność za negatywne skutki naruszenia reguł bezpieczeństwa świadczeniobiorcy"45. Należy podkreślić, że skutkiem naruszenia bezpieczeństwa pacjenta jest odpowiedzialność cywilna, karna oraz zawodowa fizjoterapeuty. W powyższym kontekście należy zwrócić uwagę na art. 102 ust. 1 u.z.f., który określa możliwość zawieszenia prawa wykonywania zawodu fizjoterapeuty. Należy zaznaczyć, że zawieszenie prawa wykonywania zawodu fizjoterapeuty może nastąpić w przypadku, gdy zebrane

43 Ustawa z dnia 6 listopada 2008 r. o prawach pacjenta i Rzeczniku Praw Pacjenta, tekst jednolity: Dz. U. z 2019 r. poz. 1127 z późn. zm. (dalej: u.p.p.).

${ }_{44}$ Wzór zgody pacjenta na świadczenia zdrowotne, zob. załącznik do uchwały Nr 292/I KRF Krajowej Rady Fizjoterapeutów z dnia 4 września 2018 r. w sprawie rekomendacji dotyczącej zgody pacjenta na świadczenia zdrowotne udzielane przez fizjoterapeutę, https:/ / kif.info.pl/file/2018/09/Uchwala_292.pdf [dostęp: 19.03.2019 r.].

45 M. Mikos i in., Bezpieczeństwo pacjenta przy wykonywaniu zawodu fizjoterapeuty, ,Journal of Education, Health and Sport" 2017, nr 7, s. 502. 
zostaną dowody, które wskazują z dużym prawdopodobieństwem, że osoba obwiniona popełniła przewinienie zawodowe, a rodzaj tego przewinienia wskazuje, że wykonywanie zawodu przez osobę obwinioną zagraża bezpieczeństwu pacjentów lub grozi popełnieniem kolejnego przewinienia zawodowego. W powyższej sytuacji sąd dyscyplinarny jest uprawniony do wydania postanowienia o tymczasowym zawieszeniu prawa wykonywania zawodu fizjoterapeuty na okres nieprzekraczający 12 miesięcy.

W przypadku ostatniego kryterium - wykorzystania wskazań aktualnej wiedzy medycznej przez fizjoterapeutę - należy uwypuklić, że pojęcie aktualnej wiedzy medycznej nie zostało określone w obowiązujących aktach prawnych. Ustawodawca precyzuje jedynie obowiązek postępowania osób wykonujących zawody medyczne zgodnie z aktualną wiedzą medyczną. Dodać należy, że obowiązek postępowania osób wykonujących zawody medyczne zgodnie z aktualną wiedzą medyczną wynika również z prawa pacjenta do świadczeń zdrowotnych, które określa u.p.p. W związku z powyższym należy przywołać art. 6 ust. 1 powyższej ustawy, który określa prawo pacjenta do otrzymania świadczeń zdrowotnych odpowiadających wymaganiom aktualnej wiedzy medycznej. Odnosząc się natomiast do zdefiniowania pojęcia aktualnej wiedzy medycznej w orzecznictwie jak i literaturze należy wskazać, że powyższe pojęcie wyznaczono w przypadku udzielenia świadczeń zdrowotnych przez lekarzy, jednak na tej podstawie można sprecyzować pojęcie aktualnej wiedzy medycznej $\mathrm{w}$ kontekście standardu wykonywania zawodu przez fizjoterapeutę.

Jak wskazuje się w orzecznictwie przez „wiedzę medyczną, która spełnia kryterium aktualności”, rozumieć należy wiadomości uzyskiwane przez lekarza w czasie studiów, dostępne w szeroko rozumianych podręcznikach, ale także kompetencje uzyskane $\mathrm{z}$ racji rozwoju naukowo-technicznego, wzbogacane dzięki doskonaleniu umiejętności zawodowych $^{46}$. Próby zdefiniowania aktualnej wiedzy medycznej podjęła się E. Zielińska wskazując, że: „będzie to zatem wszystko to, czym na danym etapie rozwoju nauk medycznych dysponują lekarze" ${ }^{47}$, "a zatem wszelkie nowości i osiągnięcia opisane w literaturze naukowej, prezentowane na zjazdach, sympozjach, czy konferencjach naukowych, a także

46 Zob. wyrok Sądu Apelacyjnego w Łodzi z dnia 27 listopada 2014 r., I ACa 745/14, LEX nr 1623928.

47 E. Zielińska, [w:] E. Zielińska (red.), Ustawa o zawodach lekarza i lekarza dentysty. Komentarz, Warszawa 2014, s. 85. 
doświadczenie życiowe lekarza"48. Natomiast T. Widłak precyzuje pojęcie „aktualnej wiedzy medycznej” w kontekście naukowym uściślając, że: „będą to te informacje, metody, techniki diagnozy i leczenia lub hipotezy wyjaśniające, które zostały obalone lub zarzucone poprzez dostarczenie dowodów przeciwnych, przy czym w nauce lub praktyce medycyny panuje w tym zakresie względny konsensus" ${ }^{49}$. Podsumowując wykorzystanie wskazań aktualnej wiedzy medycznej przez fizjoterapeutę będzie oznaczać udzielanie świadczeń zdrowotnych przez fizjoterapeutę zgodnie $\mathrm{z}$ uzyskanymi i potwierdzonymi osiągnięciami naukowymi $\mathrm{w}$ naukach medycznych $\mathrm{w}$ danym wskazaniu medycznym dotyczącym pacjenta. Należy również podkreślić, że aktualna wiedza medyczna będzie również obejmować udzielanie świadczeń zdrowotnych przez fizjoterapeutę zgodnie $\mathrm{z}$ wytycznymi i rekomendacjami przygotowanymi przez organy samorządu zawodowego fizjoterapeutów, np. Krajową Radę Fizjoterapeutów.

W kontekście oceny standardu wykonywania zawodu fizjoterapeuty należy zauważyć, że art. 6 ust. 1 u.z.f. obliguje fizjoterapeutę do współpracy z osobami wykonującymi zawody medyczne, a w szczególności lekarzami. W zakresie współpracy z osobami wykonującymi zawody medyczne art. 7 u.z.f. określa uprawnienie fizjoterapeuty do uzyskania od podmiotu udzielającego świadczeń zdrowotnych (np. od lekarza) pełnej informacji o stanie zdrowia pacjenta, rozpoznaniu, proponowanych metodach diagnostycznych, leczniczych, rehabilitacyjnych, zapobiegawczych i dających się przewidzieć następstwach podejmowanych działań, w zakresie niezbędnym do udzielanych przez siebie świadczeń zdrowotnych. W związku z tym, że przepisy u.z.f. nie precyzują formy przekazania powyższej informacji przez osoby udzielające świadczeń, możliwe jest podanie takiej informacji zarówno w formie ustnej, jak pisemnej. Dodać należy, że w sytuacji sporu z lekarzem odnośnie do zasadności realizacji zlecenia lekarza w zakresie fizjoterapii przepisy u.z.f. przyznają również fizjoterapeucie prawo domagania się uzasadnienia od lekarza, który wydał zlecenie jego wykonania, a także określają prawo odmowy wykonania określonego świadczenia przez fizjoterapeutę.

48 Zob. J. Haberko, Aktualna wiedza medyczna a stosowanie homeopatii, „Medyczna Wokanda" 2009, nr 1, s. 49.

49 T. Widłak, Interpretacja klauzuli "aktualna wiedza medyczna" w polskim prawie - zarys zagadnień epistemologicznych i metodologicznych, „Gdańskie Studia Prawnicze” 2017, t. 38, s. 610. 


\section{Zakończenie}

Standard wykonywania zawodu fizjoterapeuty określają obowiązujące akty prawne, a w szczególności przepisy u.z.f. oraz wytyczne Krajowej Rady Fizjoterapeutów.

W odróżnieniu od standardu wykonywania zawodu przez pozostałe zawody medyczne, np. ratowników medycznych, ustawodawca wskazał, że standard wykonywania zawodu fizjoterapeuty obejmuje nie tylko należytą staranność, zasady etyki zawodowej, poszanowanie praw pacjenta, wykorzystanie wskazań aktualnej wiedzy medycznej, ale również dbałość o jego bezpieczeństwo. Dbałość o bezpieczeństwo pacjenta dotyczy nie tylko ograniczeń związanych z udzielaniem świadczeń przez fizjoterapeutów posiadających tytuł licencjata lub technika fizjoterapii oraz nieposiadających wymaganego doświadczenia w powyższej profesji, ale również odpowiedzialności fizjoterapeuty za naruszenie bezpieczeństwa pacjenta. Ocena standardu wykonywania zawodu fizjoterapeuty na podstawie przyjętego stanu prawnego pozwala na stwierdzenie, że od fizjoterapeuty powinna być wymagana staranność wyższa niż przeciętna. Teza ta znajduje swoje uzasadnienie ze względu na przedmiot udzielania świadczeń zdrowotnych przez fizjoterapeutę, którym jest życie i zdrowie pacjentów.

Dokonując oceny standardu wykonywania zawodu fizjoterapeuty należy także zauważyć, że, analogicznie jak w przypadku innych zawodów medycznych, standard ten jest powiązany z przepisami u.p.p., a w szczególności dotyczy informowania pacjenta o jego prawach, udzielania pacjentowi, jego przedstawicielowi ustawowemu albo osobie bliskiej lub opiekunowi faktycznemu informacji w zakresie niezbędnym do udzielanych przez siebie świadczeń zdrowotnych, zachowania tajemnicy zawodowej oraz prowadzenia dokumentacji medycznej. Należy pozytywnie ocenić zmianę przepisów u.z.f., która weszła z dniem 1 kwietnia 2019 r. ponieważ rozszerza wykaz miejsc, w których fizjoterapeuta może wykonywać swoją profesję, jak też określa możliwość wykonywania zawodu w ramach praktyki zawodowej.

De lege ferenda należy rozważyć zmianę rozporządzenia Ministra Zdrowia z dnia 27 czerwca 2018 r. w sprawie szczegółowego wykazu czynności zawodowych fizjoterapeuty w kontekście wyodrębnienia zadań zawodowych przez fizjoterapeutów, którzy ukończyli studia I stopnia oraz osób, które ukończyły szkołę policealną, jak też sprecyzować 
kompetencje zawodowe fizjoterapeuty dotyczące nauczania, prowadzenia prac naukowo-badawczych, kierowania pracą zawodową osób wykonujących zawód fizjoterapeuty oraz zatrudnienia na stanowiskach administracyjnych.

Słowa kluczowe: standard, fizjoterapeuta, prawo

\section{Bibliografia}

\section{Źródła}

\section{Akty prawne}

Ustawa z dnia 29 sierpnia 1997 r. - Ordynacja podatkowa, tekst jednolity: Dz. U. z 2019 r. poz. 900 z późn. zm.

Ustawa z dnia 15 września 2000 r. - Kodeks spółek handlowych, tekst jednolity: Dz. U. z 2019 r. poz. 505 z późn. zm.

Ustawa z dnia 6 listopada 2008 r. o prawach pacjenta i Rzeczniku Praw Pacjenta, tekst jednolity: Dz. U. z 2019 r. poz. 1127 z późn. zm.

Ustawa z dnia 25 września 2015 r. o zawodzie fizjoterapeuty, tekst jednolity: Dz. U. z 2019 r. poz. 952.

Ustawa z dnia 22 grudnia 2015 r. o zasadach uznawania kwalifikacji nabytych w państwach członkowskich Unii Europejskiej, Dz. U. z 2020 r. poz. 220.

Ustawa z dnia 9 listopada 2018 r. o zmianie ustawy o działalności leczniczej i niektórych ustaw, Dz. U. z 2018 r. poz. 2219.

Dyrektywa 2005/36/WE Parlamentu Europejskiego oraz Rady z dnia 7 września 2005 r. w sprawie uznawania kwalifikacji zawodowych, Dz. Urz. UE L 255 z 30.09.2005, s. 22-142.

Rozporządzenie Ministra Zdrowia z dnia 20 lipca 2011 r. w sprawie kwalifikacji wymaganych od pracowników na poszczególnych rodzajach stanowisk pracy w podmiotach leczniczych niebędących przedsiębiorcami, Dz. U. z 2011 r. Nr 151, poz. 896.

Rozporządzenie Ministra Pracy i Polityki Społecznej z dnia 7 sierpnia 2014 r. w sprawie klasyfikacji zawodów i specjalności na potrzeby rynku pracy oraz zakresu jej stosowania, tekst jednolity: Dz. U. z 2018 r. poz. 227.

Rozporządzenie Ministra Zdrowia z dnia 27 czerwca 2018 r. w sprawie szczegółowego wykazu czynności zawodowych fizjoterapeuty, Dz. U. z 2018 r. poz. 1319. 


\section{Orzecznictwo}

Wyrok Trybunału Konstytucyjnego z dnia 19 października 1999 r., SK 4/99, OTK ZU 1999, z. 6, poz. 119.

Wyrok Trybunału Konstytucyjnego z dnia 2 lipca 2007 r., K 41/05, OTK ZU 2007, z. 7A, poz. 72.

Wyrok Trybunału Konstytucyjnego z dnia 24 marca 2015 r., K 19/14, OTK ZU 2015, z. 3A, poz. 32.

Wyrok Sądu Apelacyjnego w Łodzi z dnia 16 stycznia 2014 r., I ACa 1148/12, Legalis.

Wyrok Sądu Apelacyjnego w Łodzi z dnia 27 listopada 2014 r., I ACa 745/14, LEX nr 1623928.

Wyrok Sądu Apelacyjnego w Łodzi z dnia 12 kwietnia 2017 r., I ACa 1327/16, http:/ / orzeczenia.lodz.sa.gov.pl/content/\$N/152500000000503_I_ACa_ 001327_2016_Uz_2017-04-12_001 [dostęp: 16.02.2019 r.].

Wyrok Sądu Apelacyjnego w Warszawie z dnia 4 marca 2015 r., I ACa 515/14, Legalis.

\section{Literatura}

Banaszak B., Konstytucja Rzeczypospolitej Polskiej. Komentarz, Warszawa 2009.

Banaszczyk Z., P. Granecki, O istocie należytej staranności, „Palestra” 2002, nr 7/8. Borysiak W., [w:] K. Osajda (red.), Kodeks cywilny. Komentarz, t. 3a. Zobowiazania. Część ogólna, Warszawa 2017.

Haberko J., Aktualna wiedza medyczna a stosowanie homeopatii, „Medyczna Wokanda" 2009, nr 1.

Hanc J., Fizjoterapeuta, [w:] R. Kubiak, L. Kubicki (red.), System Prawa Medycznego, t. 1. Pojęcie, źródła i zakres prawa medycznego, Warszawa 2018.

Jacyszyn J., Wykonywanie wolnych zawodów w Polsce, Warszawa 2004.

Jacyszyn J., Wolność gospodarcza a wolny zawód, „Przegląd Prawa i Administracji” 2015, t. 103.

Jacyszyn J., Przedsiębiorca a wolny zawód, „Rejent” 2003, nr 10.

Jacek A., S. Porada, Aspekty prawne wykonywania zawodu fizjoterapeuty w Polsce, „Przegląd Medyczny Uniwersytetu Rzeszowskiego i Narodowego Instytutu Leków w Warszawie" 2012, z. 1.

Karkowska D., Zawody medyczne, Warszawa 2012.

Krasnowolski A., Zawody zaufania publicznego, zawody regulowane oraz wolne zawody. Geneza, funkcjonowanie i aktualne problemy, Kancelaria Senatu. Biuro Analiz i Dokunetacji, Opracowania tematyczne OT- 625, Warszawa 2013.

Kłusek P., Fizjoterapeuta jako wolny zawód i zawód zaufania publicznego, „Rozprawy Naukowe Akademii Wychowania Fizycznego we Wrocławiu" 2016, t. 53.

Łakomski M. i in., Prawne podstawy zawodu fizjoterapeuty i potrzeba ustawy o zawodzie, „Praktyczna Fizjoterapia i Rehabilitacja” 2014, nr 54. 
Migała M., Kalendarium prac nad ustawa o zawodzie fizjoterapeuty, "Rehabilitacja w Praktyce" 2015, nr 6.

Mikos M. i in., Bezpieczeństwo pacjenta przy wykonywaniu zawodu fizjoterapeuty, „Journal of Education, Health and Sport" 2017, nr 7.

Młynarska-Sobaczewska A., Zawody zaufania publicznego, [w:] W. Skrzydło, S. Grabowska, R. Grabowski (red.), Konstytucja Rzeczypospolitej Polskiej. Komentarz Encyklopedyczny, Warszawa 2009.

Paszkowska M., Ustawowe zasady wykonywania zawodu fizjoterapeuty, „Rehabilitacja w Praktyce" 2015, nr 6.

Sarnacka E., Standard wykonywania zawodu fizjoterapeuty na tle standardów wybranych zawodów medycznych, [w:] A. Górski, E. Sarnacka, M. Grassmann (red.), Standard wykonywania zawodów medycznych, Warszawa 2019.

Sarnecki P., Komentarz do art. 17, [w:] L. Garlicki (red.), Konstytucja Rzeczypospolitej Polskiej. Komentarz, t. 4, Warszawa 2005.

Widłak T., Interpretacja klauzuli ", aktualna wiedza medyczna" w polskim prawie - zarys zagadnień epistemologicznych i metodologicznych, "Gdańskie Studia Prawnicze” 2017, t. 38.

Wierdak K., M. Kiljański, „Dtugi marsz” do ustawy określającej zawód fizjoterapeuty jako samodzielny zawód medyczny, „Fizjoterapia Polska” 2015, nr 4.

Wołpiuk W.J., Zawód zaufania publicznego z perspektywy prawa konstytucyjnego, [w:] Senat Rzeczypospolitej Polskiej, Zawody zaufania publicznego a interes publiczny - korporacyjna reglamentacja versus wolność wykonywania zawodu. Materiały z konferencji zorganizowanej przez Komisje Polityki Społecznej i Zdrowia Senatu RP przy wspótudziale Ministerstwa Pracy i Polityki Społecznej pod patronatem Marszatka Senatu RP Longina Pastusiaka 8 kwietnia 2002 r., Warszawa 2002, s. 19-24, http://ww2.senat.pl/k5/agenda/seminar/a/020408.pdf [dostęp: 5.02.2019 r.].

Zielińska E., [w:] E. Zielińska (red.), Ustawa o zawodach lekarza i lekarza dentysty. Komentarz, Warszawa 2014.

\section{PHYSIOTHERAPIST PROFESSIONAL STANDARDS - ASSESSMENT OF THE ACCEPTED LEGAL STATUS}

\section{Sum mary}

The aim of this article is to assess the physiotherapist professional standards based on the accepted legal status. The article establishes the legal status of the physiotherapist's profession and assesses the standard of performing the profession using the literature and the selected judicial decisions of the common courts of law and the Constitutional Tribunal. In conclusion it is pointed out that the 
physiotherapist professional standard is defined by the legal acts in force, in particular the provisions of the Act on Profession of a Physiotherapist. The article also proposes a change in the provisions by specifying the vocational tasks of physiotherapists who have obtained a BA degree or people who have graduated from a post-secondary school, as well as specifying the professional skills related to teaching, managing work of people performing the profession and hiring administrators.

Key words: standard, physiotherapist, law

\section{СТАНДАРТ ПРОФЕССИИ ФИЗИОТЕРАПЕВТА - ОЦЕНКА ПРИНЯТОГО ПРАВОВОГО СОСТОЯНИЯ}

\section{Резюме}

Целью статьи является оценка стандарта профессии физиотерапевта на основе принятого правового состояния. В статье определяется правовой статус профессии физиотерапевта и дается оценка стандарта работы по вышеупомянутой профессии с использованием литературы и избранной судебной практики судов общей юрисдикции и Конституционного трибунала. В заключении отмечено, что стандарт профессии физиотерапевта определяется действующими правовыми документами, в частности, положениями Закона «О профессии физиотерапевта». В статье также предлагается внести поправки в положения путем выделения профессиональных заданий физиотерапевтов с высшим образованием I степени, и лиц, окончивших полицеальную школу, а также уточнения профессиональных компетенций физиотерапевта в области преподавания, ведения научно-исследовательской работы, управления профессиональной деятельностью лиц, работающих по профессии физиотерапевта, и трудоустройства на административных должностях.

Ключевые слова: стандарт, физиотерапевт, право 